\title{
Cultural sensitivity in Sámi tourism: A systematic literature review in the Finnish context
}

Ritva Saari, University of Lapland, Multidimensional Tourism Institute (MTI) Emily Höckert, University of Lapland, Multidimensional Tourism Institute (MTI) Monika Lüthje, University of Lapland, Multidimensional Tourism Institute (MTI) Outi Kugapi, University of Lapland, Multidimensional Tourism Institute (MTI) Nuccio Mazzullo, University of Lapland, Multidimensional Tourism Institute (MTI)

\section{Abstract}

The use of Sámi cultures in the Finnish tourism business has been problematic for many decades. The aim of this article is to explore how the notion of cultural sensitivity could help to find alternative approaches and new solutions to this situation, especially for Sámi tourism. For this purpose, a systematic literature review method was used to examine and describe how previous academic literature has approached the issue of cultural sensitivity in the Finnish context. While the concept has not been used in tourism research in Finland, previous discussions have focused on questions of respect, cultural sustainability, cultural carrying capacity, cultural representations and cultural identity in tourism contexts. Simultaneously, research in other fields of study has drawn attention to the importance of healing, reconciliation and recognition for Sámi cultures. Reviewing the social work and pedagogy literature indicates how the idea of cultural sensitivity can enrich the search for more responsible ways of thinking, doing and researching tourism. In sum, the article calls for future research, theoretical conceptualization and practical application of cultural sensitivity that emphasizes recognition of and respect for cultural differences.

Keywords: cultural sensitivity, respect, tourism, Sámi cultures, Finland 


\section{Introduction}

Travellers have visited Lapland for centuries and have described the Sámi in their private and public travel writings and pictures. These descriptions have often contained incorrect or biased information about the Sámi (e.g., S. Aikio, 1985). Large-scale tourism in the Finnish Lapland began in the 1920s when Petsamo became part of Finland. Especially after the road to Petsamo was built, the area attracted tourists due to its location near the Arctic Ocean, abundance of nature, fishing for salmon, Orthodox monastery and Skolt Sámi population (Ilola, 1997; Lehtola, 2012; Mäkinen, 1983; Partanen, 1992). The Sámi have been part of Lapland's tourism marketing imagery ever since (Markkanen, 1987). Since then, tourism has also been a source of income for Sámi, although this income was modest at first (Lüthje, 1995, pp. 25-26).

After World War II, many Finnish tourism companies started using Sámi elements in their marketing to differentiate Lapland from other nature-based tourism destinations (Niia, 1992; Niskala \& Ridanpää, 2016). At the same time, however, Sámi and their cultures were not visible 'enough' to tourists due to the assimilation politics of the Finnish state and modernization of the North. In order to satisfy tourists' expectations, the Finnish tourism industry started selling its own versions of Sámi cultures (Lüthje, 1995).

Nowadays, numerous Sámi engage with tourism by working in tourism companies or running their own tourism businesses. Although there exists less direct misrepresentation of Sámi cultures in tourism marketing as earlier, there are still non-Sámi tourism companies in Finland that exploit various symbols of Sámi cultures in their business (Kugapi, Höckert, Lüthje, Mazzullo, \& Saari, 2020; Niskala \& Ridanpää, 2016; Saari, 2017). The Sámi Parliament (2018) of Finland recently published its guidelines for responsible and ethically sustainable Sámi tourism. Their outspoken aim is that Sámi tourism business should be managed and owned principally by the Sámi themselves. The document underlines the importance of responsibility, ethics, carrying capacity and limits of acceptable change.

Around 10,500 Sámi live in Finland. The majority are North Sámi, and a small number are Inari and Skolt Sámi. Each of these three Sámi groups has its own language, which partly explains why we have chosen to discuss Sámi cultures as plural in this literature review. The official Sámi homeland, also called Finnish Sápmi ${ }^{1}$, is situated in the northernmost Finnish Lapland (the municipalities of Enontekiö, Inari and Utsjoki and the northern part of the municipality of Sodankylä), but many Sámi nowadays live outside this area, either elsewhere in Finland or abroad (Sámi Parliament, 2015). According to the Finnish Constitution, the Sámi have the right to maintain and develop their own language and culture as an Indigenous people (Ministry of Justice, 1999).

The use of Sámi cultures in tourism business has been problematic in Finland for many decades and is still today. It is in these settings that we explore how the notion of cultural sensitivity can offer a novel approach to the discussions and development of responsible, ethical and sustainable tourism. We are working with these issues in the project Culturally Sensitive Tourism in the Arctic (ARCTISEN). ARCTISEN is a transnational project that aims to develop a more fa-

1 Finnish Sápmi and Finnish Sámi homeland indicate the same region, but from different perspectives. 
vourable business environment for start-ups and small and medium enterprises for culturally sensitive tourism in Finland, Sweden, Norway, Greenland and Canada. Hence, this review paper is part of a larger framework of collaboration and research that is currently being conducted across the Arctic (see Hurst, Grimwood, \& Lemelin, 2019; Olsen et al., 2019; Viken, Höckert, \& Grimwood, 2019). Our systematic literature review was guided by the following question: How has the notion of (cultural) sensitivity been used in previous tourism research and other fields of study in the Finnish context?

\section{Methods}

Literature reviews can be classified into various types and methods (Kim, Bai, Kim, \& Chon, 2018; Salminen, 2011). We chose to use a qualitative systematic literature review method to study how previous academic literature has used the notion of cultural sensitivity both in Finnish language and in the Finnish context. Systematic literature reviews have been increasingly used in tourism research (Kim et al., 2018). This type of review was also used in another article in this journal (Nuottila, Jutila, \& Hakkarainen, 2017) and in reviewing the academic literature on Sámi tourism (Hägglund, Schilar, \& Keskitalo, 2019).

Conducting Keyword searches in academic databases is a common method of data collection in all types of literature reviews in the field of tourism research (see Kim et al., 2018, pp. 52-53), and this was also used in this review. We began our searches by using the General Finnish Thesaurus YSA/Finto (Finnish Thesaurus and Ontology Servicee) to define the scope of our search words, and then we chose two different databases to search for literature. The direct translation of sensitivity in Finnish is sensitivivinen. While this concept is used in the contemporary Finnish language, it cannot be found in all official Finnish thesauri because it is a loanword in the Finnish language. Therefore, it was important to include in the searches related concepts and terms that grasp the essence and idea of this notion (these concepts are presented in Table 1).

The first database used was the nationwide collection of search services called Finna, which provides free online access to material from Finnish libraries, museums and archives. We used the database to search for peer-reviewed articles, reports and theses on cultural sensitivity written in Finnish. The second database was Scopus, the world's largest database of peer-reviewed literature from scientific journals, books and conference proceedings (see Scopus.com). Scopus includes research topics across all scientific and technical disciplines. It is commonly used for literature reviews in the field of tourism research (e.g., Hägglund et al., 2019, p. 60; Hurst et al., 2019; Kim et al., 2018, p. 54; Nuottila et al., 2017, p. 69). The aim of our searches in Scopus was to find research that is written in English on the Finnish context. We acknowledge that our choice of search words and databases may have left some relevant literature outside of our review, but we feel that our choices were comprehensive enough for the purposes of this review.

We began the systematic literature review by conducting searches in Finna.fi using the Finnish search terms; the same searches were conducted in Scopus using the English transla-

2 https://finto.fi/ysa/fi/ 
tions of these search terms and adding Finland as a search term. These two searches returned 26 relevant results in total, but none of these were associated with tourism research literature.

Table 1. Results of the first round of searches.

\begin{tabular}{|c|c|c|c|}
\hline SEARCH TERMS IN FINNA.FI & SEARCH TERM IN SCOPUS & $\begin{array}{l}\text { TOTAL } \\
\text { RESULTS }\end{array}$ & $\begin{array}{c}\text { RELEVANT } \\
\text { NEW } \\
\text { RESULTS }\end{array}$ \\
\hline \multirow[t]{2}{*}{$\begin{array}{l}\text { Kulttuurisensitiivi* } \\
\text { AND matkai* OR turis* }\end{array}$} & & 2 & 0 \\
\hline & Sensitiv* AND touris* AND Finland & 14 & 1 \\
\hline \multirow[t]{2}{*}{ Sensitiivi AND matkai/turis** } & & 3 & 0 \\
\hline & $\begin{array}{l}\text { Cultur* sensitiv* AND touris* } \\
\text { AND Finland }\end{array}$ & 4 & 1 \\
\hline \multirow[t]{2}{*}{$\begin{array}{l}\text { Kulttuurisensitiivi* } \\
\text { AND saamel* OR alkuperäisk* }\end{array}$} & & 15 & 8 \\
\hline & $\begin{array}{l}\text { Cultur* sensitiv* AND Sámi* } \\
\text { OR indigenous* AND Finland }\end{array}$ & 6 & 1 \\
\hline \multirow[t]{2}{*}{ Kulttuurisensitiivi } & & 33 & 7 \\
\hline & Cultur* sensitiv* and Finland & 56 & 4 \\
\hline Kulttuurinen sensitiivi* & & 85 & 4 \\
\hline TOTAL & & 218 & 26 \\
\hline
\end{tabular}

After this phase, we expanded our search terms to Finnish synonyms for sensitivity in line with the Finnish thesauri mentioned above and conducted the following searches in Finna.fi and SCOPUS (again, adding Finland to the search terms). These searches returned 40 results that were relevant to our literature review (Table 2).

Between the searches of these two databases and the preliminary scan of abstracts, we found a total of 65 relevant results. Of these, 36 were connected to tourism, and 29 were from other fields of study. Regarding language, 24 articles were written in English and 41 in Finnish. We conducted the searches in April 2019, and the reviewed literature covers the period from 1978 to 2019. Most of the research was conducted in the last two decades. While the research written in Finnish included several master's theses, the publications written in English were primarily published as peer-reviewed articles. 
Table 2. Results of the second round of searches.

\begin{tabular}{|c|c|c|c|}
\hline SEARCH TERMS IN FINNA.FI & SEARCH TERM IN SCOPUS & $\begin{array}{l}\text { TOTAL } \\
\text { RESULTS }\end{array}$ & $\begin{array}{l}\text { RELEVANT } \\
\text { NEW } \\
\text { RESULTS }\end{array}$ \\
\hline \multirow[t]{2}{*}{$\begin{array}{l}\text { Kulttuurisensitiivi" AND matkai*/ } \\
\text { turis* AND saamel*/alkuperäisk* }\end{array}$} & & 240 & 20 \\
\hline & $\begin{array}{l}\text { Cultur* AND tourism OR } \\
\text { Indigenous tourism* AND Finland }\end{array}$ & 60 & 8 \\
\hline \multirow[t]{2}{*}{$\begin{array}{l}\text { 'Kulttuurinen kestävyys' AND } \\
\text { matkai* OR turis** AND saamel*/ } \\
\text { alkuperäisk"* }\end{array}$} & & 6 & 1 \\
\hline & $\begin{array}{l}\text { 'Cultural sustainability' AND } \\
\text { tourism AND Sámi/Indigenous } \\
\text { AND Finland }\end{array}$ & - & - \\
\hline \multirow[t]{2}{*}{$\begin{array}{l}\text { 'Kulttuurinen kestävyys' AND } \\
\text { matkai* OR turis* }\end{array}$} & & 8 & 2 \\
\hline & $\begin{array}{l}\text { 'Cultural sustainability' AND } \\
\text { tourism AND Finland }\end{array}$ & 16 & 2 \\
\hline \multirow[t]{2}{*}{$\begin{array}{l}\text { Kulttuurinen kompetenssi AND } \\
\text { matkailu }\end{array}$} & & 5 & 1 \\
\hline & $\begin{array}{l}\text { Cultural competence AND } \\
\text { tourism AND Finland }\end{array}$ & - & - \\
\hline \multirow[t]{2}{*}{$\begin{array}{l}\text { Kulttuurinen herkkyys AND } \\
\text { matkailu }\end{array}$} & & 60 & - \\
\hline & Sámi AND culture AND Finland & 53 & 5 \\
\hline TOTAL & & 448 & 39 \\
\hline
\end{tabular}

Any research associated with non-social science disciplines was excluded as non-relevant. Moreover, we excluded bachelor theses from the search. Interestingly, while the notion of cultural sensitivity was used quite often in students' theses, the concept was often loosely or undefined. For this reason, we decided to exclude those papers that had the term in the title but did not address it in the actual text. We decided not to limit our searches to only Indigenous/Sámi cultures in Finland, as this would have made the literature review quite narrow. Simultaneously, we could not go through all research on Sámi cultures that was not explicitly connected to the issue of sensitivity, as that would have included too many studies for the scope of this review. 
We thematically analyzed our findings (see Kim et al., 2018, p. 50; Salminen, 2011, p. 11). While cultural sensitivity has not been used as a concept in tourism studies in the Finnish context, our aim was to recognize issues that would be central to culturally sensitive tourism. We begin the presentation of our results with tourism research and continue with other fields of studies that have theorized and used the notion of cultural sensitivity.

\section{Themes related to cultural sensitivity in previous tourism research}

Until today, the notion of cultural sensitivity has not been used within tourism studies in Finland. That being said, it is clear that the idea of caring for, valuing and protecting cultural diversity, especially concerning Sámi cultures, has been present in the previous academic literature on tourism practices in Finland (Kugapi, 2014; Lüthje, 1995, 1998; Mällinen \& Sarkki, 2014; Niskala \& Ridanpää, 2016; Saari, 2017). Researchers have especially drawn attention to the issues of cultural carrying capacity, cultural sustainability, cultural representations and cultural identity in the context of Sámi tourism. Moreover, the idea of sensitivity has been used to refer to environmental sensitivity (Rantala \& Mäkinen, 2018; Wallace \& Russell, 2004), for instance, to the vulnerability of tourism entrepreneurs when faced with the effects of climate change during the high winter season (Tervo, 2008). Wallace and Russell's (2004) research on eco-cultural tourism in Saimaa Lake in Finland underlined the importance of the issue that planning, development and maintenance of eco-cultural sites need to be in the control of locals.

\section{Cultural carrying capacity}

Cultural carrying capacity can be connected to the notion of respect through setting limits to tourism. In the context of the Finnish Sámi homeland, Lüthje (1995) and Saarinen (2001) suggested that the cultural carrying capacity limit is exceeded when tourism causes changes that are not acceptable in the local culture. This limit is not a standard but rather varies from person to person (Lüthje, 1995, p. 76). Hence, as Lüthje (1995, p. 77) argued, tourism can also strengthen cultural carrying capacity if information about Sámi cultures is shared in correct ways and the Sámi experience their cultures are being respected by others. Saarinen (2001, p. 74) reminded that power relations are closely connected to the concept of carrying capacity; that is, questions about the limits of acceptable change and what kind of tourism development is sustainable for local cultures and economies depends on who is defining and deciding these issues.

\section{Cultural sustainability}

Cultural sustainability in tourism refers to the principles of respecting the values and culture(s) of local people and enhancing the diversity of cultural heritages (Veijola, Ilola, \& Edelheim, 2013, p. 22). The importance of respecting each other and nature are discussed in Erola and Zanasi's (2001) study concerning two aboriginal cultures in the Arctic - the Sámi of Finnish Lapland and the Inuit of Nunavut - in the context of cultural tourism and sustainability. Their research emphasized that Western and Aboriginal cultures need to cooperate equally with each other, sharing values, responsibilities and benefits. It is also important to recognize that there is an interdependence between peoples and the land. According to Erola and Zanasi, there is a gap 
between Aboriginal cultures and Western societies concerning cultural values related to the concept of sustainability. In fact, the ecologically-centred sustainability values of Aboriginal cultures are in opposition to the economically-centred sustainability values of Western societies (Erola \& Zanasi, 2001, pp. 95-96).

Mällinen and Sarkki (2014) also noted the importance of nature to the Sámi living in Finnish Lapland (see also Mällinen, 2014). Their conceptualization of cultural sustainability was similar to that of Lüthje's (1995) and Saarinen's (2001) cultural carrying capacity in that culturally unsustainable changes are undesirable to the locals (Mällinen \& Sarkki, 2014, p. 26). They defined local cultures as the daily performances or practices of the local people. In their case study of Utsjoki, these cultures take place largely in nature, and tourism should avoid altering them too much if it is to be culturally sustainable. Another important aspect in Mällinen and Sarkki's (2014) study is that Sámi culture performed for tourists is often viewed as disrespectful by the Sámi. They noted that cultural sustainability is increased by offering tourists products that are local, of high quality and true to local cultures; by respecting and appreciating the local community; by governing tourism to set limits to it; and by collaboration and participatory inclusion.

Three of the papers selected for this literature review focused on legal issues connected to cultural sustainability in the context of Sámi cultural heritage. Tervola (2012) discussed the use of cultural heritage and legitimacy in the manufacturing of souvenirs in Lapland. Tervola's (2012, p. 74) research underlined that the manufacturing of inauthentic souvenirs - those that are derogatory to Sámi cultures and promote questionable images of the Sámi people - are condemned both by the Sámi community and non-Sámi entrepreneurs. Nuorgam's (2012) study highlighted the importance of Sámi's growing awareness of their legal rights. She discussed the non-Sámi utilization of Sámi cultures, especially Sámi handicrafts, and its harmful effects both to Sámi handicrafts and cultures as a whole. Heinämäki, Magga and Ojanlatva (2016) discussed sacred sites in the Sámi homeland, especially the Käsivarsi area, evaluating how these sites should be treated in light of cultural heritage law and common laws of Indigenous peoples. Cultural heritage and sacred sites are part of the Indigenous rights of the Sámi and should be treated with respect. All three studies emphasized showing respect for Sámi cultural heritage as a part of cultural sustainability.

\section{Cultural representations}

Previous research has shown a lack of respect and sensitivity for the cultural representations of Sámi people in Finland historically. Sámi are often represented through exoticism, museumification and othering (Niskala \& Ridanpää, 2016; Seppänen, 2005). Cultural representations of alcohol use were discussed in Länsman's (2004) research. By analyzing Finnish wilderness literature from 1980 to 1990, Länsman drew attention to the ways in which the Sámi were stereotypically represented as uncivilized drunken people living wildly in nature (see also Orjasniemi \& Tiuraniemi, 2009). Another example is Varanka's (2001) research on the relation between Sámi culture, nature and tourism in Vuotso, the southernmost Sámi village in Finnish Sápmi. In her research, tourism is seen as a drama, with Sámi culture and nature acting as the setting; that is, Sámi are represented as a living historical relic. Similarly, Haataja's (2013) master's thesis examined how Forest Sámi culture has been represented in an exhibition setting and as a cultural 
tourism product at the Levi ski resort in Finnish Lapland. To counteract the drama noted in Varanka's analysis, Haataja suggested that art-based activities can be well-suited to both exhibition planning and representing cultural-historical material in a respectful way.

The ways that Sámi cultures have been used and represented in tourism marketing have been researched from many points of view. Niskala and Ridanpää (2016) and Lüthje (1995) researched ethnic representations of Sáminess in tourism promotion of Finnish Lapland using tourism brochures as their research materials. Lindholm (2014) studied how Sámi are represented on Finnish and Norwegian tourism websites written in English. These researchers showed that Sámi cultures are represented in media in marginalized, essentialized and backward ways. Moreover, two master's theses focused on cultural representations on the webpages of different organizations. Tolonen (2011) researched the construction of the image of Finnish and Swedish Lapland by official national tourism marketing organizations, whereas Saari (2017) analyzed the webpages of Sámi tourism companies in Finland, Sweden, Norway and Russia. According to these researchers, marketing organizations and companies rely on stereotypical images of the people. However, as Saari argued, some of the Sámi tourism companies represent Sámi cultures in more modern ways in their marketing material.

\section{Cultural identity}

The impact of tourism on the cultural identity of Sámi people has also been a research area of interest. These studies acknowledged that others' perceptions play a central role in the process of how cultural identities are built. Tuulentie's (2006) seminal research on the relationship between tourism and cultural identities of Sámi people in Finland, Sweden and Norway underlined that the Sámi should by no means be treated as passive victims in the tourism context because they have played an active role in constructing both their own identities and the identities of the tourists visiting the Sámi homeland. Kugapi (2014) researched the impacts of tourism on Sámi handicraft and how craftsmanship forms a central part of the Sámi cultures and identities. The most obvious example of craftsmanship is Sámi dress, which plays an important role in Sámi identities and thus should be respected in tourism. Nevertheless, as several tourism researchers have pointed out (Kugapi et al., 2020; Lüthje, 1995; Mällinen \& Sarkki, 2014, pp. 32-33), Finnish tourism entrepreneurs and workers have dressed up as Sámi for decades without recognizing or respecting these Sámi identity symbols.

Länsman's (2004) research on tourism in Sápmi discussed the importance of land for Sámi cultures and identities. While the Sámi understand the land as 'our lands', which cannot be lost without losing one's identity as Sámi, Finnish tourists tend to see the land more as scenery with wild, exotic and romantic meanings. Länsman problematized the ways in which tourism businesses and tourists consume Lapland's wilderness areas and feel that they have a legal right to use it as a resource. Hence, encounters with Sámi are often valued from the viewpoint of economic utility gained or lost (Länsman, 2004, pp. 165-166). Different apprehensions about nature were also discussed in Nykänen and Valkeapää's (2016) study. Like Länsman, they also divided perceptions of nature into Sámi's and tourists' perceptions, which are very different from each other. In Kilpisjärvi, there have been - and still are - conflicts between different ways of using nature (Kugapi et al., 2020; Länsman, 2004). In a study on the transformation of Saariselkä as a 
tourist destination within the Sámi homeland, Saarinen (2001) approached the destination as a social construction. According to Saarinen (2001, pp. 55-61), during the transformation process, there have been problems with the relationship between the Sámi and the tourism industry; the relationship 'has been characterized by separation based on cultural otherness and unequal land use priorities' (see also Mällinen \& Sarkki, 2014, pp. 30-32).

In sum, previous tourism literature shows how the use of Sámi cultures in Finnish tourism has been problematic in many ways. Respect - or the lack of it - appeared as a central topic in many of the reviewed studies. While the notion of cultural sustainability has been defined as respect toward local values, rights, cultures and communities' self-determination (Heinämäki et al., 2016; Mällinen, 2014; Nuorgam, 2012; Veijola et al., 2013, p. 22), tourism researchers in Finland have pointed out how the discussions on sustainable tourism tend to overlook the cultural dimensions of sustainability (Garcia-Rosell, 2017, p. 233; Höckert, 2011). Likewise, Mällinen and Sarkki (2014, p. 23) stated that there seems to exist 'a lack of theoretical understanding on how cultural sustainability is constituted'. Instead of seeing cultural sensitivity as something separate from cultural sustainability, we approach it as an essential constituent of it. That is, cultural sustainability requires cultural sensitivity.

Previous research has indicated how many problems centre around the ways in which Sámi cultures are represented in tourism, how essential symbols of Sámi cultures (such as Sámi dress) are used and how tourism uses Sámi land (see also Kugapi et al., 2020). These can all be seen as culturally sensitive issues, and their sensitiveness should be acknowledged and understood in all tourism activities and development. That is, in order to be culturally sensitive, tourism actors should recognize and take into account the political, historical and cultural contexts in which their tourism activities are developed (Viken et al., 2019). The next section focuses on other fields of study to gain further inspiration on how cultural sensitivity can be used in tourism research and tourism settings in general.

\section{Cultural sensitivity in other fields of study}

In previous academic literature, cultural sensitivity has often been connected to the reconciliation of the Sámi with Finnish authorities. For example, Lehtola (2015a, 2015b) and Ranta and Kanninen (2019) wrote about the classic modernization or Finnicization process, in which traditional Sámi culture was forced to integrate into modern, large-scale society. They explained that in addition to the problematic consequences of these Finnicization processes, cultural insensitivity after World War II led to Sámi ethnopolitical activism.

Research on more recent forms of political activism has examined diverse contemporary methods of cultural expression. For instance, Junka-Aikio's (2018) article examined the work of the Sámi artist and activist (i.e., artivist) group called Suohpanterror as an example of 'Indigenous culture jamming' In a somewhat similar vein, Ridanpää (2016) discussed the performances of contemporary ethnic popular music and the Sámi ethnic minorities of northern Finland within the context of critical geography and postcolonial theory. A strong emphasis on a feminist perspective of Sámi decolonization was put forth in the works of Kuokkanen $(2003,2007)$. A. Aikio's (2018) research discussed the role of museums in fostering new opportunities for rep- 
aration and healing of the traumas caused by colonization. Pennanen's (2017) study brought up the importance of concrete visits to cultural events as a way of enhancing feelings of cultural ownership, identity, empowerment and belonging.

In addition to history and political sciences, the notion of cultural sensitivity has been mainly used in the context of multicultural social work (e.g., Järvensivu, 2014) and pedagogy (e.g., Ervelius, 2018). In both fields of study, cultural sensitivity has been connected to processes of language revitalization, healing and reconciliation and to the role of recognition in respectful encounters.

\section{Revitalization, healing and reconciliation}

The interconnections between vulnerability and language loss, reconciliation and language revitalization have been written about in many studies, for example, the research on the history of assimilation practices in schools by Juutilainen, Miller, Heikkilä and Rautio (2014). In their view, Indigenous identity, culture and language are intertwined and key determinants of health. Cultural sensitivity builds on the idea of recognizing painful and traumatic experiences in people's past as a prerequisite for healing and reconciliation (see also Ervelius \& Näkkäläjärvi, 2018). The crucial role of language is equally emphasized in Sámi pedagogy (Keskitalo, Määttä, Uusiautti, Rantala, \& Paltto, 2011), questions of otherness and empowerment in school settings (Pennanen, 2017) and educational research in general (Holm, 2012; Lappalainen, 2005).

Ervelius and Näkkäläjärvi (2018) highlighted the aspect of healing and becoming stronger as fundamental to reconciliation. In concrete terms, they emphasized the role of language skills as helping to enhance the processes of healing and empowerment. In addition to the legal requirement of providing services in Sámi, Ervelius and Näkkäläjärvi elaborated how the risks of misunderstanding are significantly reduced when social workers can speak one of the Sámi languages. Järvensivu's (2014) discourse analysis of social work in the context of Sámi cultures focused on the recognition of Sámi languages and cultural aspects as a fundamental principle in both multicultural work and Finnish legislation.

Previous research in the Finnish part of Sápmi has offered some concrete examples of culturally sensitive approaches in multilingual settings. For instance, Marjaranta's (2018) research included a downloadable pocket dictionary in Finnish-Inari Sámi for practical health care needs. While the present research does not include exploration of cultural sensitivity as such, it enhances sensitive culture-based meetings. One example of communicating research and practical ideas in several languages is the book Sámi Pedagogihka Iešvuođat = Saamelaispedagogiikan Perusteet $=$ The Basics of Sámi Pedagogy = Grunderna i Sámisk Pedagogik = Osnovy Saamskoj Pedagogiki (Keskitalo et al., 2011). The purpose of this book is to support Sámi teachers' roles by answering the basic questions concerning Sámi pedagogy in five languages: North Sámi, Finnish, English, Swedish and Russian. In a similar vein, Kelly-Holmes and Pietikäinen (2016, p. 37) researched the role of language as a way to 'reinforce and also challenge existing language hegemonies and inequalities' in tourism contexts. Their research underlined the importance of recognizing the political nature of language choices, for instance, in museums and when labelling souvenirs (Kelly-Holmes \& Pietikäinen, 2014, 2016; Pietikäinen \& Kelly-Holmes 2015). 


\section{Recognition}

In many studies there was seen a call for recognition of heterogeneity within Sámi culture(s) (e.g. Järvensivu, 2014, p. 14; Valkonen, 2009, p. 11). For example, Ridanpää (2016) called for attention and sensitivity towards reproduction of stereotypical images directed at Sáminess and Northernness. He argued that over several centuries, the image of 'nature-Finland' has been constituted through various forms of 'stereotyping, mystifying, exoticizing and othering of Sámi minorities' (Ridanpää, 2016, p. 17). Stereotypes of Northernness are being disrupted in contemporary ethnic music. Similarly, Kuuva's (2017) research focused on the risks of reproducing stereotypical images of the Sámi cultures and underlined the importance of recognizing diversity in modern ways of expressing Sámi cultures. The idea of recognition towards multiple forms of cultural expressions was also central in the aforementioned research on the artivist group Suohpanterror (Junka-Aikio, 2018). Cultural sensitivity builds on recognition and respect towards Sámi cultures as living cultures that shape contemporary ways of life in multiple ways (e.g., Ridanpää, 2016).

In many studies there was seen a call for recognition of cultural values. For example, Valtonen (2008, p. 32) emphasized the importance of recognizing different kinds of values, beliefs, traditions and general worldviews. Researchers in both education and social work seemed to share concern about the ways in which Finnish institutions might fail to recognize and acknowledge Sámi worldviews (e.g., Keskitalo, 2010; Ranta \& Kanninen, 2019). The idea of recognition draws attention to cultural values and beliefs, not only among minorities but also among the majority working with them. Recognizing attitudes and ideas that might hinder fair communication with 'the Other' is needed for open dialogue (Dominelli, as cited in Järvensivu, 2014, p. 12).

The reviewed literature indicates the importance of recognizing how both listening and understanding are the core of culturally sensitive encounters. Marjaranta (2018) emphasized that health care personnel should be able to meet their patients as individuals instead of mere representatives of a cultural or ethnic group. Studies within the field of social work especially emphasize the importance of sincere face-to-face encounters in which social workers give their patients adequate space and time (Ervelius \& Näkkäläjärvi, 2018; Kunelius, 2015; Yliselä, 2018). This kind of approach is closely tied to empathy and empathic listening (Yliselä, 2018). Ervelius and Näkkäläjärvi (2018) also wrote about the willingness and desire to understand individuals and groups as a bridge between cultures.

Numerous studies viewed self-reflective learning as a valuable way to enhance cultural sensitivity. For example, Luoma and Mättö (2018) focused on the meanings of multicultural encounters in the context of early childhood pedagogies. Their view was that educators should be enabled and supported in the recognition of and reflection on their own values, thoughts, actions and feelings regarding intercultural encounters. In the same way, the case study by Rissanen, Kuusisto and Kuusisto (2016) suggested self-reflective learning processes as a method for developing teachers' intercultural sensitivity. Their research drew attention to participants' willingness to engage in self-reflection as a fundamental starting point to developing sensitive orientation towards diversity. Lappalainen (2005) suggested combining handicrafts, languages and cultures to enhance cultural sensitivity in teaching. Ervelius (2018) offered a concrete exam- 
ple of self-reflective learning as a method to enhance cultural sensitivity. The study presented a project, which consisted of an online course on Sámi culture, to develop distance teaching and learning methods in the education of nurses and deaconesses. A learning platform consisting of lecture recordings, individual and group assignments and exams is being prepared and tested in the ARCTISEN project.

Many of the aforementioned studies stressed the need for recognition of historical and political contexts, reconciliation and language revitalization (e.g., Ervelius \& Näkkäläjärvi, 2018; Juutilainen et al., 2014; Keskitalo et al., 2011). These research projects scrutinized the diverse contemporary methods of cultural expression (e.g., Junka-Aikio, 2018; Kuuva, 2017) and the risk of reproducing stereotypical images of the Sámi cultures. Several studies included the call to recognize different cultural values. Indeed, a vital aspect of culturally sensitive tourism is the recognition of and respect for Sámi worldviews, cultural values, beliefs and traditions (e.g., Valtonen, 2008).

Drawing inspiration from these discussions, we encourage readers to envision how culturally sensitive tourism could contribute to these ongoing processes and to more sensitive orientation regarding diversity. What can tourism actors learn from these other fields of study? How can they create products and services that enhance self-reflective learning processes for both hosts and guests (both international and Finnish)? What kinds of products and services could deepen one's understanding of the Sami culture(s), including their values, beliefs, traditions and contemporary lives? How could the Sámi languages be better recognized and respected in the tourism setting? What kinds of tourism encounters enable the respectful listening and understanding that form the core of culturally sensitive encounters (e.g., Marjaranta, 2018)?

\section{Concluding reflections}

Cultural sensitivity as a concept has not been used in any tourism research related to Finland or written in Finnish. In connection with the utilization of Sámi cultures in the tourism business in Finland, the main concepts studied have been cultural sustainability, cultural carrying capacity, cultural representations and cultural identity.

What then can be learnt from the other fields of studies we have reviewed? To our knowledge, healing and reconciliation, recognition of cultural values and diversity, listening and understanding as well as self-reflective learning are all concepts that so far have not often been used in tourism studies or business practices in Finnish Lapland. The Finnish tourism industry should respect Sámi cultures in its business practices, which requires understanding and recognizing Sámi cultural values and diversity, which in turn requires listening to the Sámi and practicing self-reflective learning. Every tourism entrepreneur, manager and worker should reflect on their own values, thoughts, actions and feelings towards Sámi cultures and people to become more sensitive to and respectful towards cultural diversity (see Luoma \& Mättö, 2018; Rissanen et al., 2016). Recognizing attitudes and ideas that might hinder open dialogue (Dominelli, as cited in Järvensivu, 2014, p. 12) and being willing to understand are also necessary skills. This 
applies not only to contact with Sámi cultures but with all cultures encountered by tourism industry representatives.

Respecting Sámi cultures in tourism business practices is one of the ways that healing and reconciliation can occur. While writing the concluding lines of this literature review, the newsfeeds in Finland are filled with heated discussions related to the question of cultural insensitivity and sensitivity. A former comedian and actor Pirkka-Pekka Petelius, who is currently a member of the Finnish Parliament, expressed his official apology to Sámi communities for his insensitive and directly disrespectful representations of Sámi cultures. These kinds of apologies and discussions play a vital role in the processes of reconciliation and healing. Should the Finnish tourism industry also apologize for its primitive, exotic and mystic representations of Sámi cultures? Should reconciliation and healing be objectives of tourism planning and development in Lapland (see Barton \& Leonard, 2010)?

The literature review indicates that cultural sensitivity has been, and can be, connected to many different contexts and concepts. However, the concept of cultural sensitivity differs from other concepts used in the Finnish tourism literature. For example, whereas carrying capacity brings attention to the transformation of Sámi cultures, the notion of cultural sensitivity underlines the responsibility of the Finnish tourism industry. The idea of cultural sensitivity also takes into account history, underlining the processes of healing and reconciliation as necessary due to the assimilation processes of the Sámi imposed by Finnish authorities. Reconciliation may also be needed between the Sámi and the exploitive Finnish tourism industry. Furthermore, cultural sensitivity allows for a more concrete approach to tourism discussions by underlining the importance of encountering other people with openness and respect (see Höckert, 2018). As Ervelius and Näkkäläjärvi's (2018) emphasized, cultural sensitivity consists of elements like togetherness and community. Indeed, the reviewed articles showed how sensitivity can be made possible, or challenged, in encounters between the self and the other (Kunelius, 2015; Länsman, 2004; Yliselä, 2018). As Järvensivu (2014, p. 78) stated, cultural sensitivity is at best something reciprocal, where both or all parties give and receive something. Hence, sensitivity is something that occurs in the relations between individuals or groups. In sum, based on the literature review and supported by the ARCTISEN transnational study (Olsen et al., 2019, p. 13; see also Viken et al., 2019), we suggest that responsible, culturally sensitive tourism development requires respectful, curious attitudes, that is, recognition of cultural differences while breaking down stereotypical images.

\section{Acknowledgements}

Many thanks to the informatics specialist at the University of Lapland's library who helped us to choose the right databases and to define and limit our search words. We also want to express our gratitude to our ARCTISEN project members for their inspiration and supportive teamwork. Special thanks also go to the reviewers for their insightful comments and help. 


\section{References}

Aikio, A. (2018). Guovtti ilmmi gaskkas: Balancing between two contested worlds: The challenges and benefits of being an Indigenous museum professional. Museum International, 70, 100-111. https://doi.org/10.1111/muse.12213

Aikio, S. (1985). Katsaus saamelaisten historiaan. In M. Linkola (Ed.), Lappi: Saamelaisten ja suomalaisten maa (Vol. 4, pp. 41-103). Hämeenlinna, Finland: Karisto.

Barton, A. W., \& Leonard, S. J. (2010). Incorporating social justice in tourism planning: Racial reconciliation and sustainable community development in the Deep South. Community Development, 41, 298-322. https://doi.org/10.1080j15575330903444051

Erola, P., \& Zanasi, M. (2001). Tourism and Aboriginal heritage in the Arctic as a means towards sustainability. Helsinki, Finland: Haaga Instituutin ammattikorkeakoulu.

Ervelius, T. (2018). Sairaanhoitaja-diakonissakoulutus saamelaisalueella. Helsinki, Finland: Diakoniaammattikorkeakoulu.

Ervelius, T., \& Näkkäläjärvi, T. M. (2018). Kulttuurisensitiivisyyden vahvistaminen saamelaisalueella. In M. Katisko, E. Keskitalo, M. Malkavaara, A. Määttä, A. Suikkala, \& O. Vesterinen (Eds.), Alueellisuus, paikallisuus ja globaalit mahdollisuudet (pp. 90-101). Helsinki, Finland: Diakonia-ammattikorkeakoulu.

García-Rosell, J.-C. (2017). Vastuullinen matkailu. In J. Edelheim, \& H. Ilola (Eds.), Matkailututkimuksen avainkäsitteet (pp. 229-234). Rovaniemi, Finland: Lapin yliopistokustannus.

Haataja, C. (2013). Matka metsäsaamelaisten maille: Menneisyys näytteillä Levin matkailuympäristössä (Master's thesis). University of Lapland, Rovaniemi, Finland.

Hägglund, M., Schilar, H., \& Keskitalo, E. C. H. (2019). How is 'Sámi tourism' represented in the English-language scholarly literature? Polar Geography, 42(1), 58-68. https://doi.org/10.1080/1 088937X.2018.1547327

Heinämäki, M., Magga, A.-M., \& Ojanlatva, E. (2016). Saamelaisten pyhät luonnonpaikat kulttuuriperintöoikeuden ja tapaoikeuden valossa. In T. Nykänen \& L. Valkeapää (Eds.), Kilpisjärven poliittinen luonto: Matkoja Käsivarren kulttuurimaisemassa (pp. 199-239). Helsinki, Finland: Suomalaisen Kirjallisuuden Seura.

Höckert, E. (2011). Community-based tourism in Nicaragua: A socio-cultural perspective. Finnish Journal of Tourism Research, 7(2), 7-25.

Höckert, E. (2018). Negotiating hospitality: Ethics of tourism development in Nicaraguan highlands. London, United Kingdom: Routledge.

Holm, K. (2012). Ethical, intercultural and interreligious sensitivities: A case study of Finnish urban secondary school students. Münster, Germany: Waxmann.

Hurst, C. E., Grimwood, B. S. R., \& Lemelin, H. R. (2019). Cultural sensitivity in tourism: A review of literature on the Canadian context. Paper presented at 28th Nordic Symposium on Tourism and Hospitality Research 2019, Roskilde, Denmark.

Ilola, H. (1997). Matkalla Petsamossa: Katsaus “toisen Käsivarren" matkailuun. Rovaniemi, Finland: University of Lapland. 
Järvensivu, L. (2014). Saamelaissosiaalityötä paikantamassa diskurssianalyysin keinoin (Master's thesis). University of Lapland, Rovaniemi, Finland.

Junka-Aikio, L. (2018). Indigenous culture jamming: Suohpanterror and the articulation of Sámi political community. Journal of Aesthetics and Culture, 10(4), 1-15. https://doi.org/10.1080/20004 214.2017.1379849

Juutilainen, S. A., Miller, R., Heikkilä, L., \& Rautio, A. (2014). Structural racism and Indigenous health: What Indigenous perspectives of residential school and boarding school tell us? A case study of Canada and Finland. International Indigenous Policy Journal, 5(3). https://doi. org/10.18584/iipj.2014.5.3.3

Kelly-Holmes, H., \& Pietikäinen, S. (2014). Commodifying Sami culture in an indigenous tourism site. Journal of Sociolinguistics, 18, 518-538. https://doi.org/10.1111/josl.12092

Kelly-Holmes, H., \& Pietikäinen, S. (2016). Language: A challenging resource in a museum of Sámi culture. Scandinavian Journal of Hospitality and Tourism, 16, 24-41. https://doi.org/10.1080/1 5022250.2015.1058186

Keskitalo, P. (2010). Saamelaiskoulun kulttuurisensitiivisyyttä etsimässä kasvatusantropologian keinoin (Doctoral dissertation). University of Lapland, Rovaniemi, Finland.

Keskitalo, P., Määttä, K., Uusiautti, S., Rantala, L., \& Paltto, I. (2011). Sámi pedagogihka iešvuođat = Saamelaispedagogiikan perusteet $=$ The basics of Sámi pedagogy = Grunderna i Sámisk pedagogik= Osnovy saamskoj pedagogiki. Rovaniemi, Finland: Lapland University Press.

Kim, C. S., Bai, B. H., Kim, B. P., \& Chon, K. (2018). Review of reviews: A systematic analysis of review papers in hospitality and tourism literature. International Journal of Hospitality Management, 70, 49-58. https://doi.org/10.1016/j.ijhm.2017.10.023

Kugapi, O. (2014). "Se on sydämen asia se saamenkäsityö”: Matkailun vaikutukset saamelaiseen käsityökulttuuriin ja kulttuuri-identiteettiin (Master's thesis). University of Lapland, Rovaniemi, Finland.

Kugapi, O., Höckert, E., Lüthje, M., Mazzullo, N., \& Saari, R. (2020). Kohti kulttuurisensitiivistä matkailua: Suomen Lappi. Retrieved from http://urn.fi/URN:ISBN:978-952-6620-42-8

Kunelius, M. (2015). “Se on niissä pienissä kohtaamisissa se kaikki tärkeä”: Kulttuurisensitiivisen psykososiaalisen sosiaalityön toteutuminen vastaanottokeskuksen käytännöissä (Master's thesis). University of Lapland, Rovaniemi, Finland.

Kuokkanen R. (2003). "Survivance" in Sami and First Nations boarding school narratives: Reading novels by Kerttu Vuolab and Shirley Sterling. American Indian Quarterly, 27, 697-726. https:// doi.org/10.1353/aiq.2004.0080

Kuokkanen, R. (2007). Saamelaiset ja kolonialismin vaikutukset nykypäivänä. In J. Kuortti, M. Lehtonen, \& O. Löytty (Eds.), Kolonialismin jäljet: Keskustat, periferiat ja Suomi (pp. 142-155). Helsinki, Finland: Gaudeamus.

Kuuva, P. (2017). "Semmoista, mikä on kadonnut, sitä ei nïn vaan tsimsalabim taiota esiin, vaan sitä pitää sitkeästi pyrkiä niin hyvään lopputulokseen kuin mahdollista”: Opettajien kokemuksia kielestä ja kulttuurista inarinsaamenkielisessä perusopetuksessa (Master's thesis). University of Oulu, Oulu, Finland. 
Länsman, A.-S. (2004). Väärtisuhteet Lapin matkailussa: Kulttuurianalyysi suomalaisten ja saamelaisten kohtaamisesta. Inari, Finland: Kustannus Puntsi.

Lappalainen, E. (2005). Kulttuurisesti sensitiivinen opettajuus: Käden, kielen ja kulttuurin oppimisen yhdistäminen maahanmuuttajien koulutuksessa ja opettajan kasvupolulla (Doctoral dissertation). University of Oulu, Oulu, Finland.

Lehtola, V.-P. (2012). Wallenius: Kirjailijakenraali Kurt Martti Walleniuksen elämä ja tuotanto. Retrieved from https://www.veli-pekkalehtola.fi/UserFiles/files/wallenius_nettikirja.pdf

Lehtola, V.-P. (2015a). Saamelaiskiista. Helsinki, Finland: Into kustannus.

Lehtola, V.-P. (2015b). Second World War as a trigger for transcultural changes among Sámi people in Finland. Acta Borealia, 32, 125-147. https://doi.org/10.1080/08003831.2015.1089673

Lindholm, M. (2014). The representation of Sámi people on Finnish and Norwegian tourism websites in English (Master's thesis). University of Jyväskylä, Jyväskylä, Finland.

Luoma, P., \& Mättö, T. (2018). Kohtaamisia ja kipupisteitä: Kasvatusyhteistyö varhaiskasvatuksessa monikulttuuristen perheiden kanssa (Master's thesis). University of Jyväskylä, Jyväskylä, Finland.

Lüthje, M. (1995). Matkailun vaikutukset saamelaisalueella: Näkökulmana alueen kantokyky ja saamelainen kulttuuri. Helsinki, Finland: University of Helsinki.

Lüthje, M. (1998). The impacts of tourism on the Saami domicile area from the point of view of carrying capacity and Saami culture of the area. In S. Aho, H. Ilola, \& J. Järviluoma (Eds.), Dynamic aspects in tourism development: Proceedings of the 5 th Nordic Symposium on Tourism Research (Vol. 1, pp. 31-46). Lapland, Finland: University of Lapland.

Mäkinen, V. (1983). Suomen Lapin matkailun synty. In M. Linkola (Ed.), Lappi: Suuri, kaunis, pohjoinen maa (Vol. 1, pp. 162-177). Hämeenlinna, Finland: Karisto.

Mällinen, M.-R. (2014). Matkailun kulttuurisen kestävyyden käytännön määrittelyjä ja toteutumista Utsjoen kirkonkylässä 2000-luvulla (Master's thesis). University of Oulu, Oulu, Finland.

Mällinen, M.-R., \& Sarkki, S. (2014). Tekemällä matkailun kulttuuriseen kestävyyteen: Ongelmia ja niiden hallintaa Utsjoen kirkonkylässä. Matkailututkimus, 10(2), 23-39.

Marjaranta, M. (2018). Tiervâ, mii kulloo?: Hoitotyön sanasto kohtaamisen tueksi. In T. Ervelius (Eds.), Sairaanhoitaja-diakonissakoulutus saamelaisalueella (pp. 112-116). Helsinki, Finland: Diakonia-ammattikorkeakoulu.

Markkanen, E. (1987). Harvojen harrastuksesta kansan huviksi: Matkailun vaiheet 1887-1987. In S. Hirn \& E. Markkanen, Tuhansien järvien maa: Suomen matkailun historia (pp. 147-344). Helsinki, Finland: Matkailun edistämiskeskus and Suomen Matkailuliitto.

Ministry of Justice. (1999). Suomen perustuslaki. Retrieved from https:/www.finlex.fi/fi/laki/ alkup/1999/19990731

Niia, L. P. (1992). Sámisk turism måste hitta rätt sig! Samefolket, 73(3), 30-31.

Niskala, M. , \& Ridanpää, J. (2016). Ethnic representations and social exclusion: Sáminess in Finnish Lapland tourism promotion. Scandinavian Journal of Hospitality and Tourism, 16, 375-394. https://doi.org/10.1080/15022250.2015.1108862 
Nuorgam, P. (2012). Saamelaiskulttuuri matkailun tuotteiden ja palveluiden sisältönä. In M. Lohiniva-Kerkelä (Ed.), Matkailuoikeus (pp. 335-359). Rovaniemi, Finland: Lapland University Press.

Nuottila, J., Jutila, S., \& Hakkarainen, M. (2017). Kirjallisuuskatsaus: Matkailun jakamistalous vastuullisuuden viitekehyksessä. Matkailututkimus, 13(1/2), 53-70. Retrieved from https://journal.fi/matkailututkimus/article/view/67854

Nykänen, T., \& Valkeapää, L. (2016). Kilpisjärven poliittinen luonto: Matkoja Käsivarren kulttuurimaisemassa. Helsinki, Finland: Suomalaisen Kirjallisuuden Seura.

Olsen, K. O., Abildgaard, M. S., Brattland, C., Chimirri, D., de Bernardi, C., Edmonds, J., ... Viken, A. (2019). Looking at Arctic tourism through the lens of cultural sensitivity: ARCTISEN-a transnational baseline report. Retrieved from http://urn.fi/URN:ISBN:978-952-6620-39-8

Orjasniemi, T. \& Tiuraniemi, O. (2009). Rajua, rujoa ja raitista: Alkoholin käyttöä Lapissa. Rovaniemi, Finland: Lapland University Press.

Partanen, S. J. (1992). Saariselkä: Magneettimäestä matkailukaupungiksi. Helsinki, Finland: Suomen Matkailuliitto.

Pennanen, H. (2017). Saamenluokka oppimisympäristönä: Peruskoulun saamelaisopetus 1990-2000-luvuilla oppilaiden kokemana (Master's thesis). University of Oulu, Oulu, Finland.

Pietikäinen, S., \& Kelly-Holmes, H. (2015). The local political economy of languages in a Sámi tourism destination: Authenticity and mobility in the labelling of souvenirs. Journal of Sociolinguistics, 15, 323-346. https://doi.org/10.1111/j.1467-9841.2011.00489.X

Ranta, K. , \& Kanninen, J. (2019). Vastatuuleen: Saamen kansan pakkosuomalaistamisesta. Helsinki, Finland: Kustantamo S\&S.

Rantala, O., \& Mäkinen, M. (2018). Engaging with wind shelters. In C. Ren, G. Jóhannesson, \& R. van der Duim (Eds.), Co-creating tourism research: Towards collaborative ways of knowing (pp. 131-146). London, United Kingdom: Routledge.

Ridanpää, J. (2016). 'Singing acts' from the deep North: Critical perspectives on northern exotics, contemporary ethnic music and language preservation in Sámi communities. Journal for Cultural Research, 20(1), 17-30. https://doi.org/10.1080/14797585.2015.1134057

Rissanen, I., Kuusisto, E., \& Kuusisto, A. (2016). Developing teachers' intercultural sensitivity: Case study on a pilot course in Finnish teacher education. Teaching and Teacher Education, 59, 446-456. https://doi.org/10.1016/j.tate.2016.07.018

Saari, R. (2017). Saamelaisuuden myyttiset representaatiot matkailuyritysten internet-sivuilla: Mainoskuvien semioottinen analyysi (Master's thesis). University of Lapland, Rovaniemi, Finland.

Saarinen, J. (2001). The transformation of a tourist destination: Theory and case studies on the production of local geographies in tourism in Finnish Lapland (Doctoral dissertation). Department of Geography, University of Oulu, Oulu, Finland. The Geographical Society of Northern Finland.

Salminen, A. (2011). Mikä kirjallisuuskatsaus? Johdatus kirjallisuuskatsauksen tyyppeihin ja hallintotieteellisiin sovelluksiin. Vaasa, Finland: University of Vaasa. 
Sámi Parliament. (2015). SaKä, vaalit, saamelaisten lkm 2015. Retrieved from https://dokumentit. solinum.fi/samediggi/?f=Dokumenttipankki\%2FTilastoja

Sámi Parliament. (2018). Vastuullisen ja eettisesti kestävän saamelaismatkailun toimintaperiaatteet. Retrieved from https://dokumentit.solinum.fi/samediggi/?f=Dokumenttipankki\%2FKertomukset\%2C\%20ohjelmat\%20ja\%2osuunnitelmat

Seppänen, J. (2005). Visuaalinen kulttuuri: Teoriaa ja metodeja mediakuvan tulkitsijalle. Tampere, Finland: Vastapaino.

Tervo, K. (2008). The operational and regional vulnerability of winter tourism to climate variability and change: The case of the Finnish nature-based tourism entrepreneurs. Scandinavian Journal of Hospitality and Tourism, 8, 317-332. https://doi.org/10.1080/15022250802553696

Tervola, K. (2012). Kun matkamuisto on elinkeino: Kulttuuriperinne tuotteistamisen lähteenä ja haasteena (Master's thesis). University of Lapland, Rovaniemi, Finland.

Tolonen, K. (2011). Vetovoimatekijät kohdeimagoa rakentamassa-vertailussa Suomen ja Ruotsin Lappi (Master's thesis). University of Lapland, Rovaniemi, Finland.

Tuulentie, S. (2006). The dialectic of identities in the field of tourism: The discourses of the Indigenous Sámi in defining their own and the tourists' identities. Scandinavian Journal of Hospitality and Tourism, 6, 25-36. https://doi.org/10.1080/15022250600560596

Valkonen, S. (2009). Poliittinen saamelaisuus. Tampere, Finland: Vastapaino.

Valtonen, K. (2008). Social work and migration: Immigrant and refugee settlement and integration. Burlington, VT: Ashgate.

Varanka, P. (2001). Lappi matkailun näyttämöllä: Saamelaiskulttuuri ja luonto matkailun kulisseina. Rovaniemi, Finland: University of Lapland.

Veijola, S., Ilola, H., \& Edelheim, J. (2013). Johdanto matkailun tutkimukseen. In S. Veijola (Ed.), Matkailututkimuksen lukukirja (pp. 16-29). Rovaniemi, Finland: Lapland University Press.

Viken, A., Höckert, E., \& Grimwood, B. (2019). Cultural sensitivity in tourism. Paper presented at the 28th Nordic Symposium on Tourism and Hospitality Research, Roskilde, Denmark.

Wallace, G. \& Russell, A. (2004). Eco-cultural tourism as a means for the sustainable development of culturally marginal and environmentally sensitive regions. Tourist Studies, 4, 235-254. https://doi.org/10.1177/ 1468797604057326

Yliselä, S. (2018). Maahanmuuttaja-asiakkaiden kohtaamisia sosiaalityössä (Master's thesis). University of Turku, Turku, Finland. 